\title{
HISTORIA GLOBAL DE AMÉRICA LATINA. DEL SIGLO XXI A LA INDEPENDENCIA. HÉCTOR PÉREZ BRIGNOLI. MADRID: ALIANZA EDITORIAL, 2018
}

Víctor H. Acuña Ortega

Recibido: 17/07/2018 - Aceptado: 23/07/2018

Al abrir la primera página de esta obra, he recordado que la lectura de un libro es una experiencia subjetiva, por no decir íntima; por eso se dice que no hay lectores, sino situaciones únicas e irrepetibles de lectura. No he leído muchos trabajos de síntesis de la historia latinoamericana, posiblemente por cuestiones de desempeño profesional, es decir, nunca enseñé un curso general de historia latinoamericana. La única obra que recuerdo haber leído y releído es la de Tulio Halperin Donghi, un referente intelectual y afectivo en esta historia de Héctor Pérez Brignoli. Dicho esto, mucho de lo que aquí se cuenta me es familiar; no obstante, este libro me ha mostrado fragmentos que desconocía, sea sobre la historia de Brasil, sea sobre la vida y la obra del músico Heitor VillaLobos y del pintor argentino Antonio Berni.

He hecho esta lectura en medio de la indignación, de la impotencia y en un mar de preguntas sin respuesta sobre lo que acontece actualmente en Nicaragua, algo muy latinoamericano, si se me permite sucumbir en los estereotipos. También he tomado conciencia, volens nolens, de que he sido testigo consciente de la historia aquí relatada, de al menos una cuarta parte y quizás casi la mitad de ella, si tomo en cuenta la memoria trasmitida por mi entorno familiar. Por eso, esta lectura ha sido para mí una especie de repaso por ilusiones que el tiempo y la historia marchitaron.

El autor nos propone considerar su escritura de la historia como una composición onírica, un sueño de imágenes superpuestas, recompuestas y descompuestas. En efecto, el texto se nos ofrece mediante una composición no convencional, con narrativas que se entreveran, se suceden y también parten en fuga. Así, relatos objetivos o impersonales, propios de la escritura de la historia, son "contaminados" por evocaciones subjetivas y recuerdos personales que casi resultan confesiones. De manera que el libro está jalonado de breves autorretratos.

La narrativa se organiza con yuxtaposiciones, comparaciones, conexiones y generalizaciones, nociones y conceptos, es decir, tipos ideales, y también con metáforas que sirven como trama del tejido de los relatos. El texto se despliega en un 
juego de escalas y representaciones en donde la estadística y su expresión gráfica de procesos macrosociales se engarzan con trayectorias individuales, en las cuales una palabra, una melodía y una imagen convocan historias. La obra se mueve entre las distintas esferas de la realidad social, las cuales se conectan por medio del hilo conductor de la historia política. En fin, sustentado en una impresionante erudición, el libro propone una clara síntesis y un análisis histórico sólido, vertido en una escritura llena de sensibilidad y buen gusto.

El texto se nos aparece como un objeto múltiple; podría pensarse en un collage, pero siento que no es bidimensional, sino más bien tridimensional. No es una escultura, antes bien, me recuerda a un scrapbook, en el cual están adheridos a una superficie plana objetos sin y con volumen. La obra se convierte en un paisaje donde el autor, quien se ha definido al inicio como flâneur, según la expresión de Benjamin, convierte al lector en un personaje que vaga y divaga por la historia latinoamericana. El vagabundeo por este territorio, como todo los vagares, es una experiencia multisensorial, donde desfilan ensueños cargados de sonidos y colores. El texto puede ser visto también no como un paisaje, sino como un edificio con distintas entradas, todas disponibles, al cual se puede ingresar por donde se quiera. En esta ocasión, de manera convencional, lo leí de principio a fin, pero la próxima vez entraré en sus páginas al azar de una duda o empujado por el recuerdo de una sección o de un pasaje.

Naturalmente, la obra me llevó a preguntarme sobre qué significa o qué implica pensar la historia latinoamericana. Las representaciones de esa historia son siempre metonimias, donde partes fungen como representación del todo; quizás eso sea inevitable, pero siempre salta la duda sobre si es legítimo decir que se hace historia de América Latina cuando en realidad se está hablando de sus países más importantes y de sus procesos históricos más relevantes. Quizás, por eso el recurso de composición del scrapbook, objeto siempre inacabado, tenga sentido en este caso.

Es posible que América Latina exista como objeto real, como mundo de conexiones, circulaciones e interdependencias; pero también como espacio de hiatos y ritmos diferenciados con disonancias, convergencias y recurrencias, y con actores individuales y colectivos empeñados en hacer la América Latina. Este sería un espacio de relaciones de distinta intensidad y un lugar de recorridos específicos que transitan en paralelo. La América Latina es también una cierta manera de ser y de estar en el mundo, con frecuencia vista, para utilizar un término de psicoanalista, desde el lugar de la carencia.

En este libro se intenta pensar la historia latinoamericana con una noción, utopías, y con una metáfora, la del cortocircuito. La noción de utopías me parece muy adecuada para captar la historia de América Latina como proyectos, con una mirada desde abajo, y la metáfora del cortocircuito se sitúa en un plano objetivo, donde los procesos parecen colocarse más allá de los sujetos. La metáfora de los cortocircuitos de la modernidad me 
deja a medio camino en la cuestión sobre cómo pensar Latinoamérica en perspectiva histórica, es decir, en la dialéctica de los tres tiempos: presente, futuro y pasado. La idea de cortocircuito mezcla lo casual con lo inevitable, lo cual considero que debe problematizarse. En efecto, lo que aquí se presentan como cortocircuitos son desenlaces de confrontaciones e intercambios entre diversos sujetos. Es lo que queda tras larvadas e intensas luchas entre estamentos, grupos étnicos, clases y actores individuales, internos y externos. En este sentido, los desenlaces no son accidentes, sino resultados de disputas y conflictos.

Tras la lectura de un análisis crítico de la noción de modernidad del historiador Frederick Cooper y tras tomar nota de los abusos, en términos de razonamiento y de conocimiento empírico, de nociones en boga como colonialidad y decolonialidad, creo que modernidad significa demasiadas cosas; una pluralidad de fenómenos que son concomitantes parcialmente, aunque no necesariamente empaquetables en una sola lógica de desarrollo: formación del Estado moderno, colonialismo, desarrollo del capitalismo, Revolución Industrial, Ilustración, imperialismo, entre otros. Procesos que, como insisten algunos historiadores globales, no son solamente europeos.

En América Latina, desde hace ya varios siglos, con sus sobresaltos cíclicos, la acumulación de capital ha gozado de buena salud; mientras que la razón ilustrada, la democracia y la justicia social siempre han padecido serias dolencias. Como sabemos, vivimos hoy tiempos bárbaros y el siglo XX fue el siglo de los extremos, según la expresión de Eric Hobsbawm. En un pasaje del libro, el autor recuerda a Adorno, Horkheimer, Benjamin y Arendt para señalar que, al fin y al cabo, la "modernidad" como promesa fracasada no es patrimonio exclusivo de América Latina. Habría que aceptar que los "cortocircuitos" más letales para toda la humanidad han sido los fabricados en Europa; de modo que la barbarie latinoamericana podría parecer algo menor.

En última instancia, quizás sea útil pensar la historia latinoamericana teniendo en mente la prosaica expresión "esto es lo que hay", es decir, no desde la carencia, y tratar de desentrañar las lógicas de eso que es lo que ha habido. El autor lo intenta ciertamente al proponer como hipótesis explicativa la dificultad latinoamericana para insertar y asumir el cambio tecnológico, para superar la mera adición de los factores productivos, tierra o naturaleza y trabajo, como base de los procesos de crecimiento económico. Dicha dificultad persistente es consecuencia de ciertas correlaciones de fuerzas y de determinado entorno o ambiente global, en el cual operan los procesos de acumulación de capital.

Esta obra nos incita, entonces, a repensar la historia latinoamericana, y al respecto los debates continuarán; no obstante, también es una invitación a vivir América Latina con el orgullo de la frase de Mario de Andrade "soy un tupí que tañe un laúd" y a sentirla a la sombra de una afortunada frase que su autor ha dejado en este libro: "el aire tenue, pero inconfundible de lo que algún día vendrá". 
Víctor H. Acuña Ortega. Costarricense. Doctor en Historia, profesor emérito de la Universidad de Costa Rica. Ha publicado diversos trabajos sobre historia centroamericana en los siglos XIX-XXI. Centroamérica: Filibusteros, estados, imperios y memorias, publicado en 2014, es su último libro.

Contacto: vhacuna@gmail.com

ORCID: 0000-0002-4901-7407 